\title{
IDENTIFICATION OF BACTERIA CAUSING NECROTIC PULP WITH 16S rRNA GENE POLYMERASE CHAIN REACTION AND ANTIBIOTIC RESISTANCE TESTING AT THE DENTAL HOSPITAL IN SEKELOA, BANDUNG, INDONESIA
}

\section{TINA ROSTINAWATI*, SULISTIYANINGSIH HADISOEBROTO, YOPPI ISKANDAR, PRASETYO HADI NUGROHO, AUDRIA AMANDA TARA}

Department of Biological Pharmacy, Faculty of Pharmacy, Universitas Padjadjaran, Jatinangor, Indonesia. Email: t_rostinawati@unpad.ac.id Received: 28 February 2017, Revised and Accepted: 27 March 2017

ABSTRACT

Objective: This study aims to identify the bacteria that cause necrotic pulp in teeth of dental patients and test resistance of the bacteria found to antibiotics.

Methods: Bacteria were taken with paper points that were inserted into the root canal of patients at the Dental Hospital of the Faculty of Dentistry, Universitas Padjadjaran, Sekeloa, Bandung. Bacteria were cultured and Gram-stained. Bacterial DNA was isolated to be identified by polymerase chain reactions 16S rRNA method against known sequences of bacterial DNA. Then, identified bacteria were tested for antibiotic resistance to tetracycline (30 $\mu \mathrm{g})$, clindamycin $(2 \mu \mathrm{g})$, amoxicillin $(10 \mu \mathrm{g})$, and ampicillin $(10 \mu \mathrm{g})$.

Results: The 16s rRNA gene fragment of the main bacterium found was in 98\% homology with 16S rRNA gene database in http://blast.ncbi.nlm. nih.gov, i.e., Pseudomonas aeruginosa and Acinetobacter schindleri. The results from inhibition zone of each antibiotic were $20.12 \mathrm{~mm}, 8.97 \mathrm{~mm}$, $8.12 \mathrm{~mm}$, and $8.03 \mathrm{~mm}$ for tetracycline, clindamycin, amoxicillin, and ampicillin, respectively, to P. aeruginosa. While inhibition zone of tetracycline to A. schindleri was $37.7 \mathrm{~mm}$.

Conclusion: Based on the study results, P. aeruginosa from patients with necrotic pulp samples were resistant to clindamycin, amoxicillin, ampicillin, and decreased activity to tetracycline. While Acinetobacter schindleri was still sensitive to tetracycline.

Keywords: Identification of bacteria, Necrotic pulp, Polymerase chain reaction of 16S rRNA gene, Sequencing, Antibiotic resistance test.

(c) 2017 The Authors. Published by Innovare Academic Sciences Pvt Ltd. This is an open access article under the CC BY license (http://creativecommons. org/licenses/by/4. 0/) DOI: http://dx.doi.org/10.22159/ajpcr.2017.v10i6.18205

\section{INTRODUCTION}

Thenecrotic pulp is found in a non-vital tooth that is damaged throughout the pulp (root canals), which is generally caused by microorganisms that cause cavities. Inflammatory damage will occur if the microorganism cause symptoms and clinical signs in the host. Bacteria are a major causal factor in the development of necrotic pulp and periapical disease [1]. Microorganisms get into the pulp in several ways, the most common is an open pit cavity due to dental caries. In addition, microorganisms can reach the pulp due to trauma or mechanical injury, gum sulcus, and through the bloodstream [1]. Based on data from the Household Health Survey (Household) in 2004 by the Ministry of Health of the Republic of Indonesia, the prevalence of dental caries in the population is $90.05 \%$ [2]. Pulp and periapical diseases are caused by several types of bacteria, especially anaerobic bacteria, such as Osenellauli, Eikenellacorrodens, Porphyromonas endodontalis, Peptostreptococcus, Bakterioides, Eubacterium, Staphylococcus aureus, and Fusobacterium nucleatum [3]. One treatment of necrotic pulp includes root canal irrigation with antibiotics. The solution contained the antibiotic is used to dissolve the debris resulting from root canal preparation and also to disinfect the root canal. Irrigation solution commonly used in dentistry included the class of antibiotics such as mixture of tetracycline and disinfectants and tetraclean, containing a mixture of doxycycline $500 \mathrm{mg} / \mathrm{ml}$ with propylene glycol $[4,5]$. The ability of the irrigation solution to kill bacteria had become more limited, concomitant with the discovery of genes encoding tetracycline resistance in mouth bacteria, i.e., tet (M), tet $(0)$, tet $(Q)$, tet $(W)$, tet (32), and tet (A) [6]. A large number of patients with necrotic pulp were recorded, around 122,467 and a total of 234,083 cases of complaints of oral disease in Indonesia. This indicated that recurrent therapeutic treatment is required and a possibility of antibiotic resistance in bacteria that cause necrotic pulp [7]. The fact that high rates of necrotic pulp are necessary to attempt the detection of bacteria causing the infection and the sensitivity to antibiotics that have not been reported so far in Indonesia's Dental Hospital. This study was conducted to determine the types of microorganisms that cause necrotic pulp and resistance patterns of these microorganisms to antibiotics for therapeutic effectiveness.

\section{METHODS}

The Ethical Committee approval was provided by Medical Faculty of Universitas Padjadjaran in Indonesia, Code No:041/UN6.C1.3.2/KEPK/ $\mathrm{PN} / 2016$.

\section{Sampling bacteria in necrotic pulp}

Samples were taken by one of the Hospital Dental Faculty of Dentistry, University of Padjadjaran, Sekeloa, Bandung. Samples were taken from the plaque of patients with necrotic pulp using sterilized equipment. Plaque samples were then inserted into a transport medium containing sterilized trypticase soy broth (TSB). The samples were then taken to the Laboratory of Microbiology, Faculty of Pharmacy, University of Padjadjaran, and incubated at $37^{\circ} \mathrm{C}$ for $18-24 \mathrm{hrs}$.

\section{Isolation of bacteria causing necrotic pulp}

A suspension of the incubated bacteria was then transferred to trypticase in soy agar (TSA) with the incised plate method. A total of $30 \mathrm{ml}$ of sterile TSA media was poured into a Petri dish and then allowed to solidify. A total of 1 loopful bacterial suspension taken from TSB medium and then smeared onto TSA media that had been overbooked. 
The media was incubated at $37^{\circ} \mathrm{C}$ for $18-24 \mathrm{hrs}$. Isolation was done by moving each growing bacterial colonies onto new TSA.

\section{Morphological observation of bacteria}

Observations were made with a microscope to see the colors, shapes, edges, and the elevation of bacterial colonies.

\section{Gram-staining of bacteria}

A total of 1 loopful bacteria was suspended in sterile distilled water and then was fixed on a clean glass slide. The spread of bacteria was flooded with two drops of carbolic gentian violet, and then was allowed to sit for 1 minute. Excess dye was removed, then the slide was rinsed with running water. The spread of bacteria then was flooded with two drops of Lugol 2\%, then was allowed to sit for 1 minute. Excess Lugol was discarded, then smear was faded using $95 \%$ alcohol. After rinsing with running water, the smear was flooded with 2-3 drops of $1 \%$ fuchsin, then was allowed to sit for 1 minute. Excess dye was removed, then was rinsed with water and was dried using a filter paper. The smear was covered with emersion oil and then was observed under a light microscope under $1000 \times$ magnification.

\section{Isolation of bacteria chromosomal DNA}

Isolation procedure followed the protocol of the PROMEGA ${ }^{\circledR}$ Genomic DNA Purification System. Briefly, a total of $1 \mathrm{ml}$ of the bacterial suspension in a liquid medium was put in a $1.5 \mathrm{ml}$ microtube. The tube was centrifuged for 2 minutes at $16,000 \times g$ to pellet the bacterial cells. The supernatant in the tube was removed, the cell pellet resuspended in $480 \mu \mathrm{l}$ of $50 \mathrm{mM}$ ethylenediaminetetraacetic acid. Then, $120 \mu \mathrm{l}$ of the lysozyme $(10 \mathrm{mg} / \mathrm{ml})$ was added to break down the cell walls of bacteria. The tube was incubated at $37^{\circ} \mathrm{C}$ in a water bath for 60 minutes. Thereafter, the tube was centrifuged at $16,000 \times g$ for 2 minutes at room temperature. The supernatant was discarded, then $600 \mu \mathrm{l}$ of nuclei lysis solution was added and pipetted until the entire cell pellet was homogenized. The tube was incubated at $80^{\circ} \mathrm{C}$ for 5 minutes in a water bath, then was cooled to room temperature. To eliminate RNA, $3 \mu$ l of RNase Solution $(40 \mu \mathrm{l} / \mathrm{ml})$ was added until the solution was homogeneous and was incubated at $37^{\circ} \mathrm{C}$ for 30 minutes. The tube was cooled down to room temperature, then $200 \mu \mathrm{l}$ of protein precipitation solution was added. The solution was homogenized by vortexing for 20 seconds to mix the lysate of cells with the protein precipitation solution. The solution was then incubated on ice for 5 minutes and centrifuged at $16,000 \times g$ for 3 minutes. The supernatant was transferred to a new $1.5 \mathrm{ml}$ microtube to which had been added $600 \mu \mathrm{l}$ of isopropanol. The supernatant solution with isopropanol was homogenized by inverting the tube gently. The tube was centrifuged at $16,000 \times g$ for 2 minutes. The supernatant was discarded, the tube was reversed and drained onto the tissue. The DNA pellet was added $600 \mu \mathrm{l}$ of $70 \%$ ethanol, and shaken to clean the homogeneous DNA pellets. The tube was centrifuged at 16,000 $\times g$ again for 2 minutes, then ethanol was removed and slowly dried from the tube using tissue without the precipitated DNA pellets. DNA pellets were allowed to stand for 10-15 minutes, then resuspended in $100 \mu$ of DNA rehydration solution. The solution was then stored at a temperature of $-20^{\circ} \mathrm{C}$ as a DNA sample. The obtained chromosomal DNA was detected by $1 \%$ agarose gel electrophoresis and visualized on a ultraviolet (UV) detector. Electrophoresis was performed for 40 minutes with a flow of electrical current of $100 \mathrm{~V}$. The marker used as a DNA marker had a size of $1 \mathrm{~kb}(1000 \mathrm{pb})$.

\section{Amplification of $16 S$ rRNA gene}

The 16S rRNA gene amplification was performed by polymerase chain reaction (PCR). Primers used in the amplification of $16 \mathrm{~S}$ rRNA gene were 1492R (5' GGTTACSTTGTTACGAC 3') and 27F (5' AGAgTTTGATCMTGGCTCAG $3^{\prime}$ ). Components of PCR was consisted of $2 \mu \mathrm{l}$ of $15 \mu \mathrm{M}$ primer $1492 \mathrm{R} ; 2 \mu \mathrm{l}$ of $15 \mu \mathrm{M}$ primer $27 \mathrm{~F}$; 1 $\mu \mathrm{l}$ of $10 \mathrm{mM}$ dNTP; $6 \mu \mathrm{l}$ of $\times 10$ PCR buffer (containing $20 \mathrm{mM} \mathrm{MgCl}$ ); $0.4 \mu \mathrm{l}$ of Taq polymerase $5 \mathrm{U} / \mathrm{ml}$; and $2 \mu \mathrm{l}$ DNA template and added to $50 \mu \mathrm{l}$ of nuclease-free water. All components were inserted into $200 \mu \mathrm{l}$ microtubes and homogenized. The tubes were inserted into the thermocycler. Temperature and time amplification stage was set with an initial denaturation $94^{\circ} \mathrm{C}$ for 5 minutes. Cycles consisted of denaturation step at $94^{\circ} \mathrm{C}$ for 1 minute, annealing $55^{\circ} \mathrm{C}$ for 1 minute, elongation of DNA fragments $72^{\circ} \mathrm{C}$ for 1 minute, the reaction was carried out for as many as 30 cycles. Post elongation after 30 cycles of DNA fragment was at $72^{\circ} \mathrm{C}$ for 10 minutes. The result of $16 \mathrm{~S}$ rRNA gene amplification was also detected by $1 \%$ agarose gel electrophoresis with a $1 \mathrm{~kb}$ DNA size marker and visualized on a UV detector. Electrophoresis was also performed for 40 minutes with a flow of electrical current of $100 \mathrm{~V}$.

\section{Determination of the sequence of $16 \mathrm{~S}$ rRNA gene fragment}

Determination of 16S rRNA gene sequence was performed in First BASE Laboratory, Selangor, Malaysia. Analysis of the results was performed by Basic Local Alignment Search Tool (BLAST) nucleotide sequence of 16S rRNA gene sequencing results with the database available on the site http://blast.ncbi.nlm.nih.gov.

\section{Resistance test}

Bacteria samples from the patient were assayed for resistance to some common antibiotics, i.e., tetracycline $(30 \mu \mathrm{g})$, clindamycin $(2 \mu \mathrm{g})$, amoxicillin $(10 \mu \mathrm{g})$, and ampicillin $(10 \mu \mathrm{g})$. Muller-Hinton agar liquid media (temperature $40-50^{\circ} \mathrm{C}$ ) was added to the Petri dish that already contained a bacterial suspension equivalent to a 0.5 McFarland standard. Then, the mixture was homogenized and allowed to condense. The resistance test was performed by using $10 \mu \mathrm{l}$ antibiotic containing paper disk placed on the agar medium containing the bacteria. The Petri plate was closed and incubated at $37^{\circ} \mathrm{C}$ for $18-24 \mathrm{hrs}$. The inhibition zone formed was measured using calipers.

\section{RESULTS}

\section{Isolation of bacteria from sample}

Bacteria from the necrotic pulp patient was suspended in the sterile TSB media. The result of bacteria growth in sterile TSB media is given in Fig. 1. Furthermore, bacteria were grown on sterile TSA media when it was re-incubated in solid media (Fig. 2). The observation of bacteria colonies showed that they were gray-green with a round shape, stood out and had flat edges in sample 1. Otherwise, in sample 2, the morphology of colonies had a spherical shape (cocci) as well as the edges had an irregular and flat elevation.

\section{Gram-staining of bacteria}

The bacteria isolated were Gram-negative (Fig. 3). In sample 1, the bacteria were rod-shaped. In sample 2, there were coccus-shaped bacteria.

\section{Isolation of chromosomal DNA bacteria}

The results of chromosomal DNA visualization can be seen in Fig. 4, showing one band for each sample with size more than 10,000 bp. Most bacteria have a chromosome with a size of more than $4.6 \mathrm{Mb}$.

\section{Amplification of 16S rRNA gene by PCR}

The visualization of $16 \mathrm{~S}$ rRNA gene amplification results for samples 1 and 2 showed one band of DNA with size about 1500 bp (Fig. 5). The

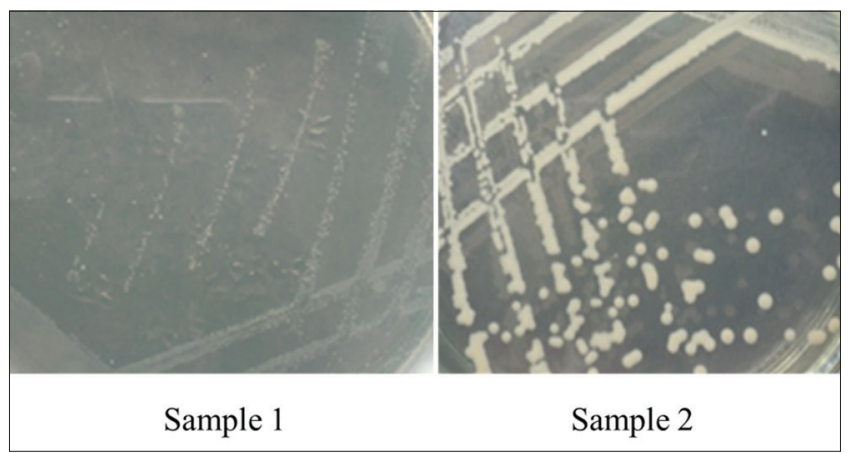

Fig. 1: Result of planting bacteria sample on trypticase soy agar media 


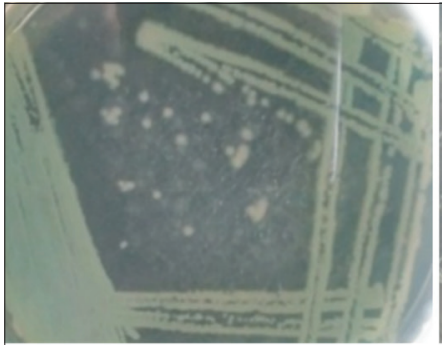

Sample 1

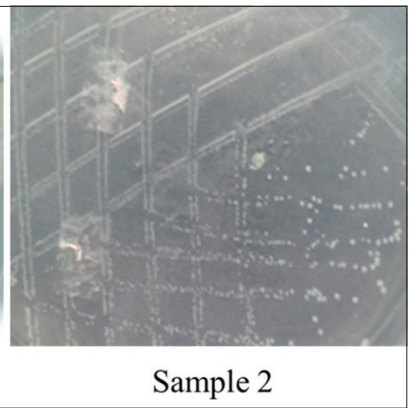

Sample 2
Fig. 2: Result of replanting single colony of bacteria samples on trypticase soy agar media

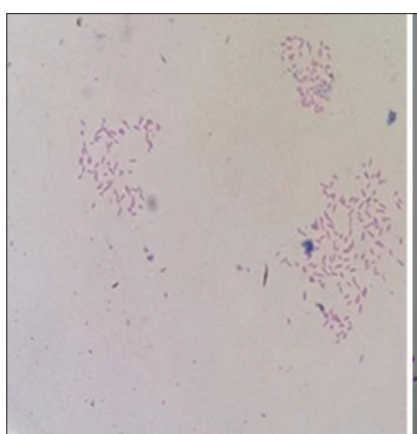

Sample 1

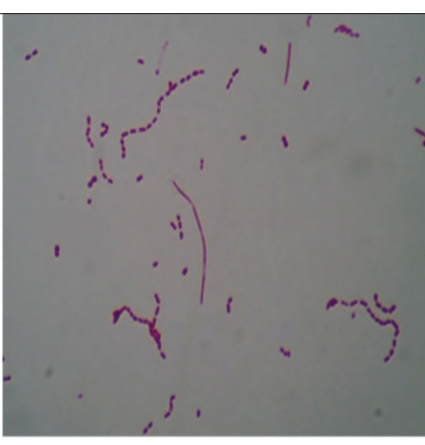

Sample 2
Fig. 3: Result of Gram-staining bacterial isolate

length of $16 \mathrm{~S}$ rRNA gene fragments was suitable with the length of DNA amplified using primers $27 \mathrm{~F}$ and $1492 \mathrm{R}$.

The results of $16 \mathrm{~S}$ rRNA gene sequencing using the $27 \mathrm{~F}$ primer showed a $1042 \mathrm{bp}$ fragment for sample 1 and $995 \mathrm{bp}$ fragment for sample 2 (Fig. 5). Results of DNA sequence alignment of $16 \mathrm{~S}$ rRNA gene fragment to the database contained on the site http://blast.ncbi.nlm. nih.gov BLAST showed that the samples of the bacteria patients with necrotic pulp had values of similarity with Pseudomonas aeruginosa and Acinetobacter schindleri, respectively, for sample 1 and 2, with $98 \%$ accuracy for both bacteria.

\section{Resistance test}

The result of $P$. aeruginosa resistance test can be seen in Table 1 was then compared with the manual resistance test that CLSI in 2007 [8]. Based on the result of resistance test, $P$. aeruginosa from a patient with necrotic pulp sample was resistant to clindamycin, amoxicillin, and ampicillin, with decreasing activity in tetracycline, which can be seen from the result of inhibition zone diameters for the four antibiotics for $P$. aeruginosa (Table 1 ). The activity test of antibiotics against $A$. schindleri only used tetracycline which had activity with an inhibition zone of $37.7 \mathrm{~mm}$ (figure not shown).

\section{DISCUSSION}

The genetic identification of $P$. aeruginosa and A. schindleri was also supported by the bacterial morphology test. The morphology observation of $P$. aeruginosa included rod-shaped bacteria, a Gramnegative and greenish gray colony while $A$. schindleri had its characteristic morphology, i.e., cocci, irregular and flat elevation. P. aeruginosa as a potential cause of necrotic pulp has not been previously reported. Root canal infections are dominated by polymicrobial anaerobic bacteria. The most microorganisms commonly found are Gram-negative anaerobic rods, anaerobic Gram-positive cocci, Gram-positive anaerobic and facultative rods, species Lactobacillus sp., Gram-positive facultative and Streptococcus species [5]. P. aeruginosa is considered to be a facultative

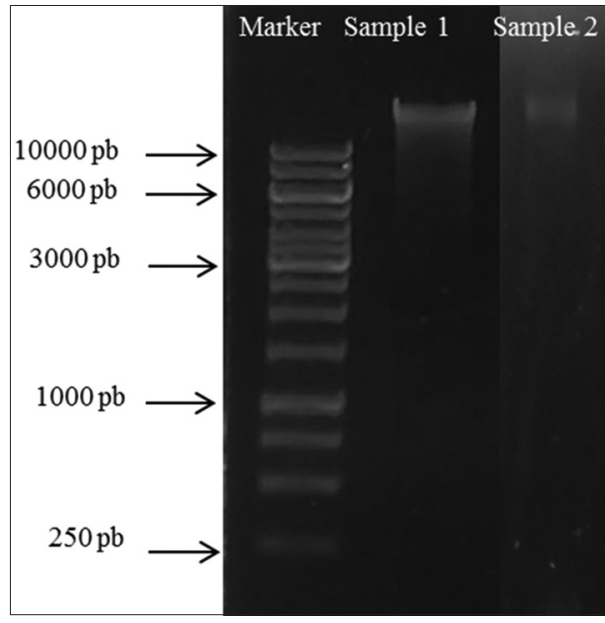

Fig. 4: Result of chromosomal DNA isolation

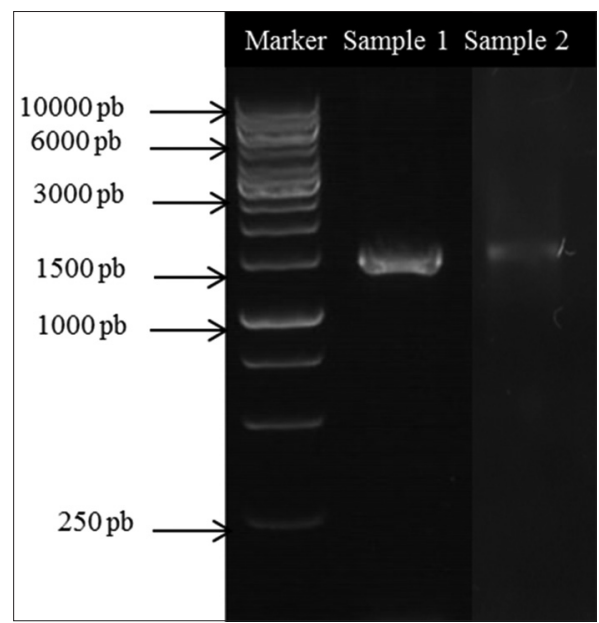

Fig. 5: Result of amplification of gene encoding bacterial $16 \mathrm{~S}$ rRNA. Sample 1: Pseudomonas aeruginosa, sample 2: Acinetobacter shindleri, M: DNA marker

anaerobe because it can live in conditions of total oxygen depletion [9]. While the Acinetobacter genus is seen as strictly aerobic, but there is species of Acinetobacter that is anaerobic facultative, i.e., Acinetobacter baumannii. Otherwise in this research found $A$. schindleri that was also classified as a definite or probable pathogen in four cases $(80 \%)$ with the potential to cause severe opportunistic infections [10]. Hence, A. schindleri is also the bacteria causing necrotic pulp that has not been previously reported. A. schindleri, lately described in 2001, initially it could be ignored as opportunistic pathogens because its ordinarily identification as phenotypic approach could not be done, due to its absence in the databases [11]. Even though Acinetobacter species is low phatogenic potential, they have increasingly been discovered as opportunistic pathogens particularly in immunocompromised patients and patients hospitalized in intensive care units [12]. Otherwise, there were many species of bacteria that were often detected in an infection in the pulp, not included Pseudomonas and Acinetobacter species, such as Dialister, Capnocytophage, Actinomyces, Porphyromonas, Eikenella, Pseudoramibacter, Corynebacterium, Tannerella, Aggregatibacter, Filifactor, Lactobacillus, Prevotella, Eubacterium, Fusobacterium, Mogibacterium, Campylobacter, Propionibacterium, Synergistes, Eggerthella, Pyramidobacter, Oise nella, Jonquetella, Bifidobacterium, Catonella, Solobacterium, Lactobacillus, Veillonella, Neisseria, Parvimonas, Streptococcus, Megasphaera, Peptostreptococcus, Enterococcus, Anaeroglobus, Finegoldia, Granulicatella, Peptoniphilus, Anaerococcus, Gamella, and Treponema [13]. For pathogenicity compared to A. schindleri, 
Table 1: Resistance test assay of $P$. aeruginosa to tetracycline, clindamycin, amoxicillin, and ampicillin antibiotics

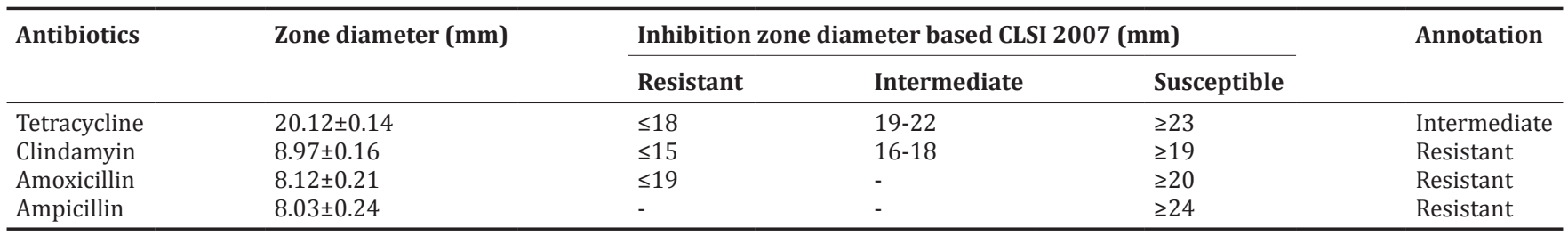

Tetracycline $(30 \mu \mathrm{g})$, clindamycin $(2 \mu \mathrm{g})$, amoxicillin $(10 \mu \mathrm{g})$, and ampicillin $(10 \mu \mathrm{g})$. P. aeruginosa: Pseudomonas aeruginosa

P. aeruginosa is more frequently associated with causing human infection; however, it naturally exists in the environment [14]. The bacterium is also regarded as an opportunistic pathogen, primarily causing nosocomial infections in immunocompromised patients $[15,16]$.

Based on resistance testing, the four antibiotics used were no longer effective to treat $P$. aeruginosa. Unfortunately, currently, tetracycline and amoxicillin are still in use in the solution irrigation in the treatment of necrotic pulp [4]; the effectiveness of the use of these antibiotics against infection in the necrotic pulp caused by P. aeruginosa needs to be evaluated. In a previous study, bacterial tooth root was still sensitive to amoxicillin and ampicillin; however, the sensitivity of bacterial tooth root to tetracycline and clindamycin was decreased [17]. $P$. aeruginosa has become a major cause of nosocomial bacterial infections especially in immunosuppressed patients who need prolonged hospitalization [18]. It had been reported, P. aeruginosa isolates, samples were obtained from patients who were hospitalized for more than 1 week duration, that was from a tertiary care hospital in Punjab, India, had become resistance to cephalosporins (60\%), cefotaxime $(75 \%)$, ceftriaxone $(63 \%)$, ceftazidime and amikacin (41.5\%), gentamicin (79\%), ciprofloxacin (73.2\%), piperacillin (44\%), and lower resistance was seen to imipenem (3.7\%) [19]. From another result of $P$. aeruginosa isolates had shown that imipenem and amikacin were the most effective antibiotics [20]. Otherwise, the other antibiotics had performed the resistance to $P$. aeruginosa were ciprofloxacin (32\%), $\beta$-lactamase inhibitor (piperacillin) (34\%), third generation (ceftazidime) (36\%), netilmicin (40\%), and gentamicin (48\%) [20]. Antibiotic resistant - P. aeruginosa are strongly associated with nosocomial infections, that are a worldwide health concern due to the increasing development of multidrug resistance (MDR) strains (i.e. resistance to at least three antibiotics) [21]. Various therapeutic challenges exist with MDR $P$. aeruginosa due to the limit of effective treatment strategies. The current literature strongly associates inadequate empirical treatment with increased rates of mortality and morbidity [22]. P. aeruginosa is intrinsically resistant to various antibiotics due to a low permeability of its the outer membrane, which acts as a selective barrier [23]. Resistance mechanisms of $P$. aeruginosa include producing the enzyme that inactive antibiotics, an antibiotics efflux system, and decreased the permeability of the outer membrane bacteria [24]. For A. schindleri, it is said to have resistance if it has a diameter of $1.8 \mathrm{~cm}$ below the inhibitory zone [8]. Thus, it was concluded that the antibiotic tetracycline is effectively used as a treatment for necrotic pulp caused by A. schindleri. Studies by Dortet et al. [10] the strains of $A$. schindleri showed they were susceptible to penicillin, cefuroxime, ceftazidime, cefepime, and imipenem, whereas other $\beta$-lactams performed a variable activity. They were similar susceptible to aminoglycosides, quinolones, chloramphenicol, tetracycline, and colistin. Almost all strains were resistant to fosfomycin (80\%) and trimethoprim (70\%), while they were variably susceptible to rifampin, sulfonamide, and furans [10].

\section{CONCLUSION}

P. aeruginosa and $A$. schindleri were Gram-negative bacteria founded in necrotic pulp teeth in patients in Dental Hospital, Sekeloa, Bandung, Indonesia. Based on this data, the necrotic pulp can also be caused by opportunistic bacteria.

\section{REFERENCES}

1. Garg N, Garg A. Textbook of Endodontics. $2^{\text {nd }}$ ed. New Delhi: Jaypee Brothers Medical Publishers; 2011.

2. Pradono P, Soemantri J, Soeharsono S. Survei Kesehatan Nasional: Survei Kesehatan Rumah Tangga (SKRT) 2004. Jakarta: Departemen Kesehatan, Badan Penelitian dan Pengembangan Kesehatan, Pusat Penelitian dan Pengembangan Pelayanan dan Teknologi Kesehatan; 2005.

3. Rôças IN, Siqueira JF Jr. Root canal microbiota of teeth with chronic apical periodontitis. J Clin Microbiol 2008;46(11):3599-606.

4. Rhodes JS. Advanced Endodontics. $1^{\text {st }}$ ed. London, New York: Informa Healthcare; 2006.

5. Jaju S, Jaju PP. Newer root canal irrigants in horizon: A review. Int J Dent 2011;2011:851359.

6. Mullany P, Allan E, Warburton PJ. Tetracycline resistance genes and mobile genetic elements from the oral metagenome. Clin Microbiol Infect 2012;18 Suppl 4:58-61.

7. Soepardi J. Profil Kesehatan Indonesia Tahun 2009. Jakarta: Kementerian Kesehatan Republik IndonesiaI; 2010.

8. Clinical and Laboratory Standards Institute (CLSI). Performance Standards for Antimicrobial Susceptibility Testing. Approved Standard M100-S16 2006. Wayne, PA, USA: National Committee for Clinical Laboratory Standards; 2016.

9. Balcht AL, Smith RP, editors. Pseudomonas aeruginosa: Infections and Treatment. New York: Marcel Dekker, Inc.; 1994.

10. Dortet L, Legrand P, Soussy CJ, Cattoir V. Bacterial identification, clinical significance, and antimicrobial susceptibilities of Acinetobacter ursingii and Acinetobacter schindleri, two frequently misidentified opportunistic pathogens. J Clin Microbiol 2006;44(12);4471-8.

11. Nemec A, De Baere T, Tjernberg I, Vaneechoutte M, van der Reijden TJ, Dijkshoorn L. Acinetobacter ursingii sp. nov. and Acinetobacter schindleri sp. nov, isolated from human clinical specimens. Int J Syst Evol Microbiol 2001;51:1891-9.

12. Humphreys H, Towner KJ. Impact of Acinetobacter spp. in intensive care units in Great Britain and Ireland. J Hosp Infect 1997;37(4):281-6.

13. Siqueira JF Jr, editor. Treatments of Endodontics Infections. $1^{\text {st }}$ ed. London: Quintessence Publishing; 2011.

14. Coggan KA, Wolfgang MC. Global regulatory pathways and cross-talk control Pseudomonas aeruginosa environmental lifestyle and virulence phenotype. Curr Issues Mol Biol 2012;14(2):47-70.

15. Riou M, Carbonnelle S, Avrain L, Mesaros N, Pirnay JP, Bilocq F, et al. In vivo development of antimicrobial resistance in Pseudomonas aeruginosa strains isolated from the lower respiratory tract of intensive care unit patients with nosocomial pneumonia and receiving antipseudomonal therapy. Int J Antimicrob Agents 2010;36(6):513-22.

16. Brown SP, Cornforth DM, Mideo N. Evolution of virulence in opportunistic pathogens: Generalism, plasticity, and control. Trends Microbiol 2012;20(7):336-42.

17. Skucaite N, Peciuliene V, Vitkauskiene A, Machiulskiene V. Susceptibility of endodontic pathogens to antibiotics in patients with symptomatic apical periodontitis. J Endod 2010;36(10):1611-6.

18. Griffith SJ, Nathan C, Selander RK, Chamberlin W, Gordon S, Kabins S, et al. The epidemiology of Pseudomonas aeruginosa in oncology patients in a general hospital. J Infect Dis 1989;160(6):1030-6.

19. Arora D, Jindal N, Kumar R, Romit R. Emerging antibiotic resistance in Pseudomonas a challenge. Int J Pharm Pharm Sci 2011;3(2):82-4

20. Sivaraj S, Murugesan P, Muthuvelu S, Purosutaman S, Silambarasan A. Comparative study of Pseudomonas aeruginosa isolate recovered from clinical and environmental samples against antibiotics. Int J Pharm Pharm Sci 2012;4(3):103-7.

21. Garner JS, Jarvis WR, Emori TG, Horan TC, Hughes JM. CDC definitions for nosocomial infections, 1988. Am J Infect Control 
1988;16(3):128-40.

22. Aloush V, Navon-Venezia S, Seigman-Igra Y, Cabili S, Carmeli Y. Multidrug-resistant Pseudomonas aeruginosa: Risk factors and clinical impact. Antimicrob Agents Chemother 2006;50(1):43-8.

23. Bredenstein EB, de la Fuente-Nunez C, Hancock RE. Pseudomonas aeruginosa: All roads lead to resistance. Trends Microbiol 2011;19(8):419-25.

24. Meletis G, Bagkeri M. Pseudomonas aeruginosa: Multi-drug-resistance development and treatment options. In: Basak S, editor. Infection Control. Croatia: InTech Publisher; 2013. p. 33-56. 